\title{
PENGEMBANGAN MEDIA WHEELS QUESTION PADA MATERI SISTEM KOLOID UNTUK MENINGKATKAN MOTIVASI BELAJAR SISWA KELAS XI DI SMA NEGERI 12 BANJARMASIN
}

\author{
The Development of Wheels Question Media on Colloid Material to \\ Increase Student's Motivation Learning Class XI In SMA Negeri 12 \\ Banjarmasin
}

\author{
Ummi Khairunnisa, Okviyoandra Akhyar, Raden Roro Ariessanty Alicia Kusuma \\ Wardhani \\ Program Studi Pendidikan Kimia Fakultas Keguruan dan Ilmu Pendidikan \\ Universitas Islam Kalimantan (Uniska) Muhammad Arsyad Al Banjari, Banjarmasin \\ *e-mail: Ummykhairunnisa15@gmail.com
}

\begin{abstract}
Abstrak. Koloid merupakan salah satu materi kimia yang cukup sulit dan cenderung hafalan. Materi koloid memiliki subpokok bahasan yang cukup luas untuk dipelajari dan dipahami, sehingga membuat kurangnya motivasi belajar siswa dalam mengikuti pembelajaran kimia. Pada penelitian ini peneliti tertarik untuk mengembangkan media wheels question yang dapat meningkatkan motivasi belajar siswa pada materi sistem koloid. Jenis penelitian yang digunakan adalah penelitian pengembangan denganmetode Research and Development (R\&D) dengan menggunakan langkah 1 sampai langkah 6. Populasi yang digunakan adalah kelas XI IPA SMAN 12 Banjarmasin dengan sampel kelas XI IPA 3 yang berjumlah 25 orang siswa. Selain menguji kelayakan media, penelitian ini juga menguji efektivitas media terhadap motivasi belajar. Hasil penelitian pengembangan media wheels question ditinjau dari analisi kelayakan media wheels question memperoleh penilian sebesar 64 berada pada rentang $X>63$ sehingga termasuk kedalam kategori sangat baik dan peningkatan motivasi belajar siswa sebesar $43 \%$.
\end{abstract}

Kata Kunci: Koloid, motivasi belajar, wheels question

\begin{abstract}
Colloid is a chemical material that is quite difficult and tends to memorize. Colloid material has a fairly broad sub-topic to be studied and understood, thus making students lack of learning motivation in taking chemistry learning. In this study, researchers are interested in developing the wheels question media that can improve students' learning motivation in the colloidal system material. The type of research used is development research with Research and Development $(R \& D)$ method using stes 1 through step 6. The population used is class XI science at SMAN 12 Banjarmasin with a sample of class XI IPA 3 totaling 25 student. In addition to determine the feasibility of media, this study also determine the effectiveness of media to learning motivation. The results of the wheels question media develoment research were reviewed from the feasibility analysis of wheels question media obtained a score of 64 in the range $X>63$ so that it was included in the excellent category and an increase in student learning motivation by $34 \%$.
\end{abstract}

Keywords: Colloid, learning motivation, wheels question 


\section{PENDAHULUAN}

Pendidkan adalah proses untuk menentukan tumbuh kembangan individu dalam masyarakat. Undang - undang nomor 20 tahun 2003 menyebutkan bahwa pendidikan sebagai usaha sadar dalam perencana untuk mewujudkan proses pembelajaran sehingga siswa secara aktif dapat mengembangkan potensi yang dimilikinya. Jadi belajar merupakan kunci yang paling penting dalam setiap usaha pendidikan, sehingga tanpa belajar sesungguhnya tidak ada pendidikan. Pelaksanaan pendidikan dalam pembelajaran ini hendaknya siswa tidak boleh lagi dianggap sebagai obyek pembelajaran, akan tetapi siswa ikut berperan aktif sebagai agen pembelajaran,Sedangkan guru hnaya bertindak sebagai fasilitator. (Widyawati dkk, 2016)

Pembelajaran merupakan suatu interaksi antara siswa dengan guru serta sumber belajar pada suatu lingkungan belajar. Pembelajaran yang diberikan oleh guru hendaknya dapat terjadi proses pemolehan ilmu dan pengetahuan, penguasaan dan kemahiran dan tabiat, serta pembentukan sikap dan kepercayaan pada siswa. Dengan kata lain, pembelajaran dapat dikatakan sebagai proses untuk membantu siswa dalam belajar.

Berdasarkan hasil wawancara dengan guru di SMAN 12 Banjarmasin dimana siswa kurang termotivasi terhadap pembelajaran kimia dikarenakan gurunya saja yang aktif menerangkan. Ada pun media yang sering dipakai pada saat pembelajaran menggunakan power point untuk media wheels questionbelum pernah dilakukan pada saaar pembelajaran. Salah satu contoh pokok bahasan yang membuat siswa cenderung pasif adalah pembelajaran koloid, peranan koloid dalam bidang industri, serta dalam pembuatan koloid karena materi koloid merupakan materi konseptual. Guru hanya mengajarkan konsep dan teori yang kadang susah di jangkau oleh pemiliran siswa. Sehingga siswa kurang termotivasi terhadap pembelajaran kimia.

Motivasi adalah faktor yang mendorong seseorang untuk melaksanakan tugasnya sebagai siswa dengan penuh semangat sehingga akan meningkatkan hasil belajar, perlu dilakukan inovasi pembelajaran yang memperhatikan kesesuaian antara model dan media pedukung dengan karakteristik materi yang disampaikan agar tujuan pembelajaran dapat tercapai seperti yang diharapakan. Untuk mengatasi hal ini dibutuhkan media pembelajaran yang membuat siswa lebih aktif dalam kegiatan belajar mengajar untuk mencapai hasil belajar yang maksimal. (Mahrus, 2015).

Penggunaan media wheels question dilatar belakangi faktor kesesuaian terhadap materi, serta adanya faktor kesesuian gaya belajar, yang biasanya guru menerapkan metode pembelajaran yang kurang menarik. Penelitian ini memilih media wheels question pada pembelajaran kimia karena masih kurang peneliti yang menggunakan media ini dalam jurusan pendidikan kimia. Adapun materi yang dipilih adalah materi sistem koloid karena materi sistem koloid hanya berupa materi tanpa ada perhitungan.

Media permainan wheels question atau bisa disebut dengan roda pertayaan merupakan media permainan yang dikemas untuk melatih keaktifan menjawab siswa dan mengetahui motivasi siswa dalam mengikuti pembelajaran dikelas. Permainan ini bisa digunakan pada materi yang dirasa cukup sulit dipahami oleh siswa. Media wheels question merupakan media mengajar dengan memutar roda pertanyaan, kemudian setiap siswa yang memutar pertanyaan dimana roda tersebut berhenti akan diberikan pertanyaan - pertanyaan yang ada pada kartu soal tersebut. 
Media wheels question ini memiliki beberapa kelebihan pada pengembangnnya dalam pembelajaran, yaitu (1) wheels question merupan suatu permainan yang menyenangkan dan juga tidak membosankan, (2) memungkinkan adanya keterlibatan dari siswa untuk belajar, (3) keinginan untuk terus mencoba sampai mendapatkan nilai yang diinginkan, dan (6) selalu terus berusaha mempertahankan jawaban pertanyaan agar dapat memperoleh nilai yang ditawarkan, (Muchlis dkk, 2016).

\section{METODE PENELITIAN}

Penelitian pengembangan (Research and Development / R\&D) media wheels question menggunakan desain Brog and Gall langkah 1- 6 (Lindasari, 2016). Penelitian uji efektifitas media terhadap motivasi belajar menggunakan desain one group pretestposttest design. Analisis data yang digunakan untuk kelayakan media adalah deskriptif sedangkan dan analisis data untuk uji efektivitas media terhadap motivasi belajar siswa menggunakan uji $t$ dependent berbantuan sofware SPSS tipe v16,0.

\section{HASIL DAN PEMBAHASAN}

Penelitian ini dilakukan di SMAN 12 Banjarmasin pada tanggal 2 April sampai 16 April 2018. Populasinya adalah semua siswa - siswi kelas XI IPA dengan sampel kelas XI IPA 3. Penelitian ini merupakan penelitian R \& D (Research and Development) dengan produk yang dihasilkan media wheels question. Pengembangan produk menggunakan desain Brog and Gall yang dilakukan dari langkah pertama sampai langkah keenam yaitu pendahuluan sampai uji produk tahap luas kesekolahan terhadap motivasi belajar siswa.

Desain media pembelajaran wheels question untuk materi sistem koloid

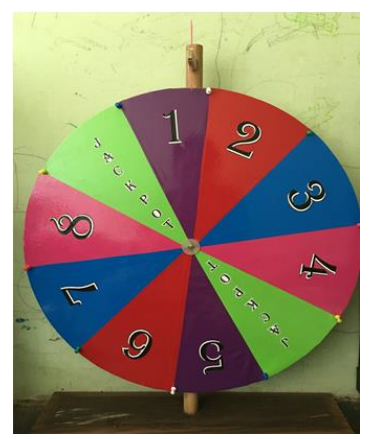

Gambar 1 Media Wheels Question

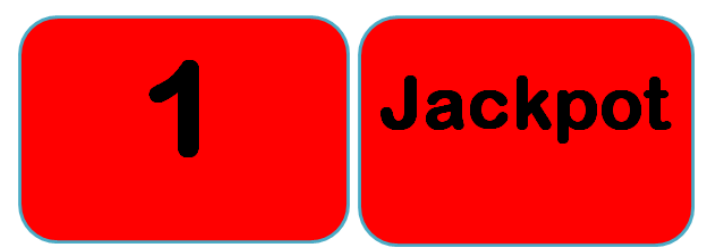

Gambar 2 Desain bagian kartu media wheels question 


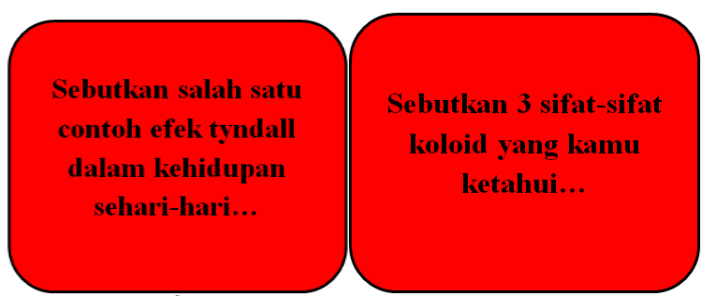

Gambar 3 Desain bagian belakang kartu media wheels question

Adapun hasil uji kelayakan media wheels question oleh para ahli oleh setiap aspek peniliannya dilakukan oleh 2 dosen 1 guru dan 10 siswa di SMAN 12 Banjarmasin dengan nilai rata - rata yang didapatkan 64 berada pada rentang $X>63$ sehingga termasuk kedalam keriteria sangat baik. Selanjutnya produk diuji kembali lebih luas kesekolah adapun pada siswa kelas XI IPA 3 dengan jumlah 25 siswa. Adapun hasil uji media wheels question pada materi sistem koloid untuk meningkatkan motivasi belajar siswa.

Validitas isi angket motivasi belajar siswa dari 50 butir angket yang diuji diperoleh 35 butir angket yang valid dan 15 butir angket yang tidak valid. Berdasarkan hasil uji validitas isi angket motivasi diperoleh persentase sebesar $91 \%$ ada pada kriteria sangat baik. Adapun hasil uji validasi isi angket motivasi oleh validator sebagai berikut :

Tabel 1 hasil uji validitas isi angket motivasi

\begin{tabular}{|c|c|c|c|c|}
\hline \multirow[t]{3}{*}{ Skor } & \multicolumn{4}{|l|}{ Indikator } \\
\hline & Menunjukkan minat belajar & & & 9,9 \\
\hline & Semangat, tekun, & mandiri, & dalam & pembelajaran \\
\hline 0 & Senang & terhadap & guru & kimia \\
\hline & Senang & kerja & & kelompok \\
\hline 13,5 & Berprestasi & dalam & & belajar \\
\hline & Total & & & 91 \\
\hline & Persentase & & & $91 \%$ \\
\hline
\end{tabular}

Perhitungan rata-rata hasil pengisian angket motivasi belajar oleh siswa sebelum menggunakan media wheels question dan setelah menggunakan media wheels question adalah sebagai berikut :

Tabel 2 Rata - rata nilai sebelum dan setelah angket motivasi belajar siswa

\begin{tabular}{|c|c|c|}
\hline $\begin{array}{c}\text { Nilai } \\
\text { menggunakan media }\end{array}$ & $\begin{array}{l}\text { sebelum menggunakan media } \\
\text { wheels question }\end{array}$ & $\begin{array}{r}\text { setelah } \\
\text { wheels question }\end{array}$ \\
\hline Terendah & 73 & 133 \\
\hline Tertinggi & 91 & 162 \\
\hline Rata - rata & 81,32 & 142,44 \\
\hline Selisih & 61,12 & \\
\hline Persentase & $43 \%$ & \\
\hline
\end{tabular}


Berdasarkan tabel diatas didapatkan hasil bahwa nilai rata - rata sebelum dan setelah menggunakan media wheels question hasil motivasi belajar siswa diketahui nilai rata - rata sebelum menggunakan media 81,32 . Sedangkan pada setelah menggunakan media nilai rata - rata adalah 142,44. Perbedaan ini terjadi karena adanya penggunaan media wheels question yang mempengaruhi motivasi belajar yang dicapai. Sehingga didapat perpsentasenya sebesar $43 \%$.

Pada analisis uji t dependent dihitung berdasarkan hasil angket motivasi dari sebelum dan setelah menggunakan media wheels question. Berdasarkan data yang diperoleh, angket motivasi di uji validitas isi terdahulu untuk mengetahui butir angket yang mana saja yang valid yang bisa digunakan untuk mengukur motivasi belajar. Setelah mendapatkan nilai sebelum dan setelah menggunakan media wheel question maka selanjutnya dilakukan uji hipotesis menggunakan uji $\mathrm{t}$ dependent dengan menggunakan software SPSS 16.0 for windows, diperoleh nilai sig. 0.000, dari hasil penelitian tersebut dapat dihasilkan bahwa sig $<\alpha$, maka $\mathrm{H} 0$ ditolak dan $\mathrm{H} 1$ diterima. Dengan kenaikan hasil motivasi belajar siswa sebesar $43 \%$ dengan menggunakan media wheels question pada materi sistem koloid. Penelitian menggunakan media wheels question ini untuk meningkatkan motivasi belajar siswa didukung oleh hasil penelitian yang telah dilakukan sebelumnya oleh Muchlis dkk( (2016) dengan judul "Pengembangan permainan question wheel sebagai media pembelajaran untuk melatih keaktifan menjawab dan meningkatkan hasil belajar siswa pada materi jamur di Sampang. Nilai yang diperoleh dari hasil penelitian yaitu hasil penelitian pengembangan media permainan question wheel ditinjau dari aspek keaktifan menjawab siswa memperoleh penilaian sebesar 85,31\% dengan kategori sangat baik dan hasil belajar siswa sebesar 100\% dengan kategori sangat baik. Sedangkan oleh Khairunnisa (2017) dengan judul "Pengembangan media permainan roda putar berbasis website untuk keterampilan membaca bahasa Prancis siswa kelas XI SMA Angkasa Adisutjipto" dengan hasil penelitiann yaitu dengan hasil penilaian dari ahli materi sebesar $86,67 \%$ dalam kategori "Sangat Baik" untuk diujicobakan, ahli media sebesar 94,12\% dalam kategori "Sangat Baik" untuk diujicobakan, dan dari tanggapan siswa sebesar 76,98\% dalam kategori "Setuju" untuk digunakan sebagai media dalam pembelajaran bahasa Prancis.

\section{SIMPULAN}

Berdasarkan hasil dan pembahasan di atas maka dapat disimpulkan bahwa media wheels question pada materi sistem koloid layak sebagai media pembelajaran dan efektif menigkatkan motivasi belajar siswa sebesar $43 \%$.

\section{DAFTAR RUJUKAN}

Khairunnisa, W. (2017). Pengembangan Media Permainan Roda Putar Berbasis Website Untuk Keterampilan Membaca Bahasa Prancis Siswa Kelas XI SMA Angkasa Adisutjipto. Skripsi. Jurusan Pendidikan Bahasa Prancis Universitas Negeri Yogyakarta. Yogyakarta.

Lindasari, A. (2016). Pengembangan Modul Pembelajaran Kimia Berbasis Pedagogical Content Knowledge Untuk Materi Pokok Struktur Atom Terhadap Kemandirian Belajar Siswa. Skripsi. Program Studi Pendidikan Kimia Universitas Islam Kalimantan Muhammad Arsyad Al - Banjari. Banjarmasin 
Dalton : Jurnal Pendidikan Kimia dan Ilmu Kimia, Volume 2 Nomor 1, Mei 2019

Mahrus, M. (2015). Meningkatkan Motivasi Belajar Siswa Melalui Media Pengembangan Audio Visual Pada Mata Pembelajaran Akidah Akhlak Di Madrasah Aliyah Negeri (MAN) Bondowoso. Skripsi. Jurusan Pendidikan Agama Islam Universitas Islam Negeri Maulana Malik Ibrahim. Malang

Muchlis, F.N.U., Isnawati., Trimulyono, G. (2016). Perkembangan Permaian Question Wheel Sebagai Media Pembelajaran Untuk Melatih Keaktifan Menjawab Dan Meningkatkan Hail Belajar Siswa Pada Materi Jamur. BioEdu, 5(3), 271-276.

Widyawati, R. L., Utomo, S. B., Saputro, S. (2016). Penerapan Model Pembelajaran Teams Games Tournaments (TGT) Dilengkapi Flash Chemquiz Untuk Meningkatkan Minat Dan Prestasi Belajar Materi Hidrokarbon Pada Siswa Kelas X-8 SMA Negeri 3 Boyolali Tahun Pelajaran 2015/2016. Jurnal Pendidikan Kimia, 5(4), 75-82. 